\title{
Assessment of Cowpea (Vigna Unguiculata(L.) Walp) Germplasm for Agronomic Traits in Seed Production
}

\author{
${ }^{1}$ Magashi A. I., ${ }^{2}$ Gaya A.G., ${ }^{3}$ Daraja Y.B.. and ${ }^{4}$ Isah S.D. ${ }^{5}$ Ado $\mathrm{M}^{\cdot}{ }^{6}$ Almu H. ${ }^{7}$ Ahmad D. and ${ }^{8}$ Umar I.
}

\begin{abstract}
A tremendous increase in production of cowpea depends on the introduction of improved varieties and better methods of high quality cowpea seed production, resistance to stress factors, high nutritional value, short vegetation period and high yielding potential. The study was conducted to identify different cowpea varieties which will perform better under specific drought condition with subsequent evaluation of the germplasm for agronomic traits pertinent to seed production. Cowpea germplasm comprising of fortyfive (45) genotypes were assessed for agronomic traits in seed production under Gaya conditions, at the KUST experimental field station, during 2013-2015 rainy seasons. The germplasm were obtained from the genes banks and from farmers in Kano and Niger republic respectively. All the forty five germplasm were characterized based on the following parameters: incidence and severity of diseases, agronomic traits as indicators of drought tolerance, grain yield, and earliness and evaluated for days to seedling emergence, germination percent, leaf formation, days to flowering, days to pod formation, number of pods per plant, number of seeds per pod and weight of 100 -seeds varied significantly $(\mathrm{P}=.05)$ between genotypes The findings revealed that the less incidence and severity of seed rot, cowpea mosaic, cowpea mottle virus disease, bacterial blight, and anthracnose and nematode infections were recorded in favor of genotypes;KUST-FA-13-35, and KUST-FA-13-41. Genotypes KUSTFA-13-35, KUST-BK-13-4 and KUST-BK-13-5 took between 3-5 days to emerge with $80 \%$ percentage emergence and took 14 days from planting to $50 \%$ flowering. They have relatively high number of pod per plant number of seeds per pod, highest 100 seed weight with less severity and incidences of diseases. Therefore these varieties are considered to be the best genotypes for seed production under GayaKano State conditions.
\end{abstract}

Keywords - Cowpea, Germplasm and Agronomic traits, Seed..

1Magashi A. I., 2 Gaya A.G.., 3 Daraja Y.B.. and 4 Isah S.D. 5Ado M. 6Almu H.7Ahmad D. and 8Umar I. .

$1,2,3,5 \& 8$ Department of crop science, Faculty of Agriculture and Agricultural Technology, Kano University of Science and Technology, Wudil, Kano State.

4Department of Forestry fisheries and wild life

6Department of soil science

7Department of Agricultural economics and extension

Corresponding author: Magashi A. I Department of Crop Science, Kano University of Science and Technology, Wudil, Kano State, Nigeria. Email magashi2@yahoo.com. Mobile phone: +2348023627191 and $+2348037173580$

\section{INTRODUCTION}

$\mathrm{M}$ ORE than half of the populations of the people of Kano state are farmers and they practice subsistence farming. The small scale commercial farming is so insignificant that it does not even commensurate with amount of agricultural produce required to the State. There is need to come up with a realistic strategy of boosting sustainable agricultural production, which may not only ensure food security in the State but will enhance the empowerment of common citizen, making them more self-reliant and prosperous. A tremendous increase in food supply at the age of green revolution of mid20th century resulted in the introduction of better methods of production and improved seed of cultivated crop. [15]

Cowpea (Vigna unguiculata L) is the second most important class of food crops grown, providing man with food and feed and is a major source of protein, minerals and vitamins in daily human diets and is equally important as nutritious fodder for livestock among the popular crops grown in Central and West Africa, [1,4 and 17].

Grain yield and its quality are primary breeding objectives of nearly all cowpea breeding programs. The accomplishments of some of these programs have been described by others [11 and 12]. To achieve sustainable crop productivity, maximum yield and quality crop, varieties with potential for high quality cowpea seed need to be identified and consider as an important aspect of cultural practice. Understanding the quantitative characters of varieties for potential seed production will pave way to elucidate the genetic factors responsible for all the identified traits.[3] Consequently, the genes identified can be manipulated to the advantage of farmers.

A lot is known about the extent and structure of genetic variation, and the potential for cowpea crop improvement through domestication, selection and/or breeding of most indigenous cowpea, A number of factors pose as a hindrance to its cultivation. For instance, its relatively low yield is also an impediment to commercial production [2 and 6]

The study was conducted to assess cowpea germplasm for agronomic traits pertinent to seed production a recommend best varieties with resistance to stress factors, high nutritional value, short vegetation period and high yielding potential. Thus enabling cowpea seed producers to receive a boom and solve several problems to come when human population will reach 
10 billion in the nearer future

\section{MATERIAL AND METHODS}

\section{A. Genotypes selection}

Forty-five (45) genotypes were evaluated for agronomic traits and seed production under KUST Research farm-Gaya conditions in 2014-2015 rainy seasons. The germplasm included 45 genotypes (Table1), which were obtained from the genes banks and from farmers in Kano and Niger republic (Zinder, Matamaye, Magaria, Mirria, Birnin Konni, Maradi and Gidan Rumji), respectively and a commercial type, was included as a check

\section{B. Experimental Procedure}

The genotypes were grown in KUST Farm Plot Gaya , during 2014 and 2015 rainy seasons. Two seeds of each genotype were planted per plot. The varieties were arranged in a completely randomized design (RCBD) with three replicates.

The land was prepared to produce a firm fine seedbed. With emphasis placed on making the bed firm enough to allow for a relatively shallow seed placement. Planted at $2 \mathrm{~cm}$. This was expected to allow moisture to move upward in the soil profile and provides more upward in the soil profile and provides more moisture for the germinating seed. The standard field management practices were strictly observed. Weed spectrum was assessed and an appropriate weed control program was used.

The harvesting begun when two-thirds to three-quarters of the seed pods have turned dark brown or black.

\section{Data collection and Analysis}

Data on desirable traits was scored based on; incidence and severity of some diseases, and recorded days to seedling emergence, germination percent, leaf accumulation, days to flowering (vegetable production traits), days to pod formation, pods per plant, number of seeds per pod and weight of 100 seeds (seed production traits). Day to flowering was taken when $50 \%$ of the plants had flowered while days to pod formation was recorded when $50 \%$ of the plants had formed pods. To determine pods per plant, ten plants were randomly selected per genotype in the three replicates and the number of pods in each one of them counted when fully formed and an average number of pods calculated using the data from the ten plants in the three replicates. Similarly for the determination of number of seeds per pod, ten plants were randomly selected in each genotypes for each of the replicates and 5pods were pick at random from each of the plants and the seeds contained in each pod was counted and recorded and eventually an average per plant calculated. The 100 seed weight was determined by counting 100 seeds of each of the genotypes replicated three times and weighed using a sensitive weighing balance and an average for the 100 seeds calculated. The data collected were subjected to analysis of variance using Genstat statistical package and means were compared using Fisher's protected
LSD at $\mathrm{P}=0.05$.

\section{RESULTS AND DISCUSSIONS}

\section{A. Incidence and severity of diseases}

Incidence and severity of the following disease were observed and recorded see Tables.3, 4, 6, 8, 10, 12 and19: Seed rot disease, Cowpea mosaic virus, Cowpea mottle carmovirus, Cowpea aphid-borne mosaic virus, Bacterial blight, anthracnose and Nematode infection. The less incidence and severity of seed rot, cowpea mosaic, cowpea mottle virus disease, bacterial blight, anthracnose and nematode infections were recorded in favor of genotypes; KUST-BK-13-2 and KUST-FA-13-41 . (Table 20 ).

\section{B. Days to seedling emergence}

Genotypes differed significantly $(\mathrm{P}=.05)$ in the number of days taken from planting to seedling emergence (Table 21). The days to emergence ranged between 3 days 10 days (table 21). Sixteen out of the 45 genotypes evaluated took 3 to 6 days to emerge and only 6 took longer (8-10 days) to emerge compared to others. Temperature and light have been shown to have a significant influence on germination of cowpea, where best conditions for seed germination are 20-30 0 C in darkness. Besides, proper processing of seed determines the quality of the seed for example sun-drying of cowpea plant seeds improve the mean germination time, seedling vigour and overall germination percent compared with shade dried seeds. In addition, majority of the genotypes used were obtained from the Gene bank having been stored for a long period and therefore there is need for regeneration of germplasm stored in the gene bank periodically.

Cowpea seeds are negatively photosensitive and the effects of photo inhibition increases at temperatures lower than $20 \mathrm{oC}$ and germination is also influenced by physiological maturity of the seeds. The consequence of genotypes that take a long time to germinate may result in a poor final plant stand and hence low yields per unit area. The longer seeds are in the soil before germination or the slower the germination, the greater the chances are for soil disease and insects to attack the seeds. [8 and 10].

\section{Germination Percent}

There were no significant differences among genotypes for germination percent (Table 21). The germination percent ranged from 10 to $100 \%$. Only two genotypes KUST-BK-13-4 and KUST-BK-13-5 had a germination of $100 \%$, while Genotypes KUST-BK-13-9, KUST-BK-13-10 and KUST-DM13-11 had germination ranged from $10 \%-20 \%$. The number of plants established from a given weight of seed depends on size of seeds and percent of those seeds that are viable and can grow into established plants.

\section{Days to $50 \%$ Flowering}

The number of days to flowering varied significantly $(\mathrm{P}=.05)$ among genotypes (Table 21).The shortest duration to flowering 
was 11 days for (KUST-BK-13-3, KUST-BK-13-5, KUSTDN-13-12 and KUST-BK-13-2), whereas the longest period to flowering was 18 days. KUST-BK-13-4, KUST-BK-13-6, KUST-DM-13-14 and KUST-MR-13-20.

\section{E. Pods per Plant}

The number of pods per plant varied significantly $(\mathrm{P}=.05)$ among genotypes (Table 22). The lowest number of pods per plant (2) was recorded in KUST-KD-13-18 and KUST-BK-137 and highest number of pods per plant (30) was recorded in KUST-BK-13-10. Majority of genotypes had between 8 and 20 pods per plant. The primary components of seed yield are number of pods per plant and seed weight. Seed yield is a complex character with polygenic inheritance having positive or negative effects on yield component traits. In other crops, seed yield is strongly correlated with number of pods per plant. Taking this into account, genotype with high number of pod per plant would be expected to yield more seed than genotypes that have a lower number of pods per plant. However, this can only be concluded after assessing the seed weight of different genotypes. Salehi et al. reported that the result of stepwise multiple regression analysis based on seed yield as a dependent variable and other traits as independent variables, pods per plant explained $83.2 \%$ of the total variation suggesting that the number of pods per plant may be the main factor determining seed yield.

\section{F. Seeds per Pod}

There were significant variations of genotypes for the number of seeds per pod (Table 22 ). The highest number of seeds per pod (11-13 seeds/ pods) was recorded in 17 genotypes, while the lowest number of seeds (7 seeds) per pod was recorded in DAN-YAGAJI. The number of seeds in a pod can vary widely among plant species, individual plants within a species and fruits within a plant. Factors and processes affecting seed production might be achieved with studies that incorporate variation at all these levels.

\section{G. 100-Seed weight}

The genotypic effect was significant $(\mathrm{P}=.05)$ for 100-seed weight (Table 22). The 100-seed weight is one of the most important criteria in seed quality determination. It determines embryo size and seed storage for germination and emergence. High 100-seed weight increases germination percent and seedling emergence. Thus, seed weight has a large effect on seed germination, seed vigor, seedling establishment and yield production. For commercial purposes, genotypes with a high seed weight will be preferred by farmers as seeds are sold by weight.

\section{G. Grain Yield}

Table 23 shows that KUST-FAR-13-42 recorded the highest $(\mathrm{P} \leq 0.001)$ grain yield among the 45 varieties investigated. However, UST-FA-1329, KUST-FA-13-30, KUST-MG-1322), KUST-KD-13-188 and KUST-FA-13-40 recorded the lowest $(\mathrm{P} \leq 0.001)$ grain yield with no significant difference with some varieties.

\section{CONCLUSION}

The less incidence and severity of seed rot, cowpea mosaic, cowpea mottle virus disease, bacterial blight, anthracnose and nematode infections were recorded in favor of genotypes; KUST-BK-13-2, and KUST-FA-13-41. KUST-BK-13-2, KUST-BK-13-4 and KUST-BK-13-5 took between 3 days to emergence, had 80-00 percentage emergence and took 14 days from planting to $50 \%$ flowering, with relatively high number of pod per plant number of seeds per pod especially KUST-BK13-2 (Table ) they are considered to be the best genotypes for production under Gaya, Kano, Sudan Savannah. Whereas genotypes; KUST-FA-13-44, KUST-FA-13-41, KUST-FA-1331, KUST-DM-13-12, KUST-MR-13-19 and KUST-KD-13-17 took more than 24 days from planting to $50 \%$ flowering, produced 2-18 pods per plant . Genotypes KUST-BK-13-2 was found to be the best performing under Gaya-Kano State conditions.

\section{REFERENCES}

[1] Alyenemy, M.N (1998). Effect of drought and growth and yield of cowpeas (Vigna unguiculata L), Vol. 10 Science (1), $41-51$

[2] Ashley, J. (1993). Drought and crop adaptation. Pages 46 - 67 on dryland Farming in Africa, edited by J.R.J Rowland Macmillan Press Ltd, UK.

[3] Aryeety, A.N and liang, E. (1973). Inheritance of yield components and their Correlation with yield of cowpea (VignaUnguiculata (L) Walp) Euphytica 22: 386 - 396

[4] Barett, R.P (1990): legumes species as leaf vegetables in: Janick, J, and simon, J.E (Eds). Advance in new crop

[5] Bates, L.S., R.P. Waldren, and I.O. Teare. 1973. Rapid determination of free proline in water stress studies. Plant and Soil 38: 205.

[6] Cisse, N, Ndiaye, M. Thiaw, S, Hall, A.E, (1978). Registration of melakli Cowpea crop science 37

[7] Ceccarelli, S. And S. Grando (1996). Drought as a challenge for the plant Breeder plant growth regulators, 20: $149-155$

[8] Dennis R. Decoteau (2005). Principles of plant science Inc. Ch17, PP 295

[9] Ehlers.J.D, Hall, A.E, (1998). Heat tolerance of contrasting cowpea

[10] Evans. L.T (1974), the physiological basis of crop yield in evans, L.T. (ed) Crop physiology press $327-355$

[11] Hall, A.E, R.G. Mutters, K.T. Hubick, and G.D. Farquhar. 1990. Genotype differences in carbon isotope discrimination by cowpea under wet and dry fi eld conditions. Crop Science 30: 300-305.

[12] Hall, A.E., S. Thiaw, A. Ismail, and J.D. Ehlers. 1997. Water-use effi ciency and drought adaptationof cowpea. Pages 141-146 in Advances in cowpea research, edited by B.B. Singh, D.R. Mohan

[13] Krishnamurthy, L.C, C. Johansen, and O. Ito. 1996. Genotypic variation in root system development and its implication for drought resistance in Chickpea. Pages 235-250 in Roots and nitrogen in cropping systems of the semiarid tropics, edited by O. Ito, C. Johansen, J.J. Adu-Gyamfi, K.Katayama, J.V.K. Kumar Rao, and T. J. Rego. JIRCAS and ICRISAT, Hyderabad, India 
[14] Morgan, J.M. 1984. Osmoregulation and water stress in higher plants. Annual Review of Plant Physiology 35: 299-319.

[15] Raj, K.E. Dashiell, and L.E.N. Jackai. Copublication of International Institute of Tropical Agriculture (IITA) and Japan International Centre for Agricultural Sciences (JIRCAS). IITA, Ibadan, Nigeria.

[16]Sadras, V.O, and S.P. Milroy (1996). Soil - Water thresholds for the Responses of leaf expansion and gas exchange: A review. Field Crop Res, 47 $253-266$

[17] Singh, B.B., O.L. Chambliss, and B. Sharma. 1997. Recent advances in cowpea breeding. Pages $30-49$ in Advances in cowpea research, edited by B.B.

TABLE 3

INCIDENCE OF SEED ROT DISEASE ON 45 COWPEA VARIETIES

\begin{tabular}{|c|c|}
\hline Variety & Means \\
\hline Dan wuri (Mai Bakin Hanci) & $100(1.57) \mathrm{a}$ \\
\hline Jangau (Magarya)) & $100(1.57) \mathrm{a}$ \\
\hline Dan wuri (Mai Jan Hanci) & $100(1.57) \mathrm{a}$ \\
\hline TN-121-87 & $95.83(1.34) \mathrm{ab}$ \\
\hline IT 89 & $86.11(1.06) \mathrm{bc}$ \\
\hline TN 257-87 & $72.22(0.84) \mathrm{cd}$ \\
\hline TN-578 (Red variety) & $70.83(0.79) \mathrm{cde}$ \\
\hline IN 92E-26 & $68.06(0.75) \mathrm{cdef}$ \\
\hline $\begin{array}{l}\text { Gidimount (Jan } \\
\text { wake)(Mirya) }\end{array}$ & $51 . .39(0.63) \mathrm{cdefgh}$ \\
\hline KD-97 & $47.22(0.66) \mathrm{cdefg}$ \\
\hline IT-96D-610 & 47.22(0.49)defghi \\
\hline Dan mora (Kwanar & 45.83(0.49)defghi \\
\hline \multicolumn{2}{|l|}{ Dangora) } \\
\hline Dan misra (Rano) & 45.83(0.50)defghi \\
\hline Oloka (Mirya) & 44.78(0.49)defghi \\
\hline IT89KD-374-57 & 44.45(0.49)defghi \\
\hline IT90K-372-1-2 & 41.67(0.43)defghi \\
\hline KVX & 41.60(0.43)defghi \\
\hline TN5-78 & 40.28(0.42)defghi \\
\hline Haladu Kadawa & 35.06(0.37)defghi \\
\hline IT90K-372-1-2 & 33.51(0.34)efghi \\
\hline Dan wuri(Mai feshi) & 31.94(0.34)efghi \\
\hline Kyambas (Darki) & 31.94(0.33)efghi \\
\hline Danbathage (North) & 30.56(0.31)efghi \\
\hline Dan Dukku (Darki) & 29.17(0.30)fghi \\
\hline Mai Fitila & 29.17(0.30)fghi \\
\hline IT99k-573-1 & 27.78(0.28)fghi \\
\hline Danyagaji & 24.38(0.27)fghi \\
\hline Oloka(Magaria NR) & 23.6(0.24)ghi \\
\hline TN-2780 & 20.83(0.22)ghi \\
\hline TN 3-78 & 20.83(0.21)ghi \\
\hline Kanannado (Kwanar & 19.78(0.20)ghi \\
\hline \multicolumn{2}{|l|}{ Dangora) } \\
\hline Sama'ila & 19.44(0.20)ghi \\
\hline Kanannado (Rano) & $17.00(0.18)) \mathrm{ghi}$ \\
\hline TN5-78 & 16.67(0.17)hi \\
\hline KVX-100-2 & 16.66(0.17)hi \\
\hline KVX 30-309-64 & $13.89(0.14) \mathrm{hi}$ \\
\hline TN 256-87 & $11.44(0.11) \mathrm{i}$ \\
\hline
\end{tabular}

Farin wake

IT98K-497-4

TT 90

TN $5-78$

TN 28-87

DNT-07

IT 98K 205-8

Dan illa 11.11(0.10)i

8.67(0.09)i

8.67(0.09)i

8.33(0.08)i

4.83(0.05)i

3.44(0.03)i

$2.06(0.02) \mathrm{i}$

2.06(0.02)i

S. E. +

19.46

Means followed by the same letters are not significantly $(\mathrm{P} \leq 0.001)$ different according to Duncan's Multiple Range Test (DMRT). Means in parentheses are transformed values

TABLE 2

LABORATORY ANALYSIS, \% OF THE COLLECTED GERMPLASM 2013/2014 Varieties/gnotypes Sesd viasilty Germination Sead puity Dead

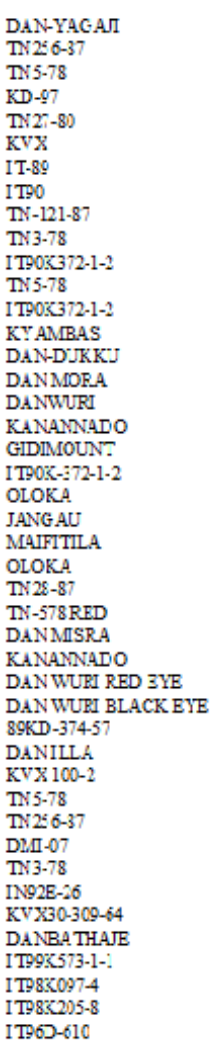

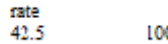

$\begin{array}{lll}\text { rate } \\ 42.5 & 100 & 0 \\ 17.5 & 100 & 0\end{array}$

$27.5-100$

$75-100$

$80-100$

$42.5-100$

$82.5-100$

10

$32.5-100$

$40-100$

$37.5-100$

$32.5 \quad 100$

$45 \quad 100$

$52.5 \quad 100$

$\begin{array}{ll}72.5 & 100 \\ 10 & 100\end{array}$

$60 \quad 100$

$17.5 \quad 100$

$32.5 \quad 100$

$32.5 \quad 100$

100

$\begin{array}{ll}12.5 & 100 \\ 67.5 & 100\end{array}$

$70 \quad 100$

100

$\begin{array}{ll}42.5 & 100 \\ 40 & 100\end{array}$

$30 \quad 100$

82.51100

$72.5 \quad 100$

$90 \quad 100$

7.5100

$\begin{array}{ll}22.5 & 100 \\ 50 & 100\end{array}$

$45 \quad 100$

$25-100$

$\begin{array}{ll}70 & 100 \\ 87.5 & 100\end{array}$

$\begin{array}{lll}5 & 100 & 4\end{array}$

TABLE2 3

GRAIN YIELD (KG/HA)

\begin{tabular}{ll} 
Variety & Means \\
\hline IT 98k-497-4 & $2668.7 \mathrm{a}$ \\
IT99k-573-1 & $2346.1 \mathrm{ab}$ \\
Dan dukku (Darki) & $2288.5 \mathrm{abc}$ \\
TN3-78 & $2112.8 \mathrm{abcd}$ \\
IT96D-610 & $2050.4 \mathrm{abcde}$ \\
IT98K 203-8 & $1722.2 \mathrm{abcdef}$ \\
Dan illa & $1698.4 \mathrm{abcdef}$ \\
Sama'ila & $1533.7 \mathrm{abcdefg}$ \\
Mai fitila & $1485.9 \mathrm{abcdefg}$ \\
IN-92E-26 & $1272.4 \mathrm{abcdefg}$ \\
Dan mora(Kwanar Dangora) & $1270.0 \mathrm{abcdefg}$
\end{tabular}


TT 90

IT 90K-372-1-2

Kyambas (Darki)

Haladu Kadawa

Dan wuri (Mai feshi)

KVX

KD-97

Oloka (Magaria NR)

IT 89KD-374-57

DNT-07

TN5-78

TN28-87

TN256-87

IT 90K-372-1-2

TN-2780

TN 257-87

Kanannado (Rano)

KVX30-309-64

TN5-78

Farin wake

TN5-78

TT 89

Gidimount (Jan Wake)

TN-121-87

KVX-100-2

TN-578

Oloka (Mirya)

Danyagaji

Dan misra

Danbathage (North)

Kanannado (Kwanar

Dangora)

Dan wuri (Mai Jan Hanci) $\quad 0.0 \mathrm{~g}$

Jangau

Dan wuri (Mai Bakin Hanci)

$0.0 \mathrm{~g}$

$0.0 \mathrm{~g}$

$0.0 \mathrm{~g}$

1122.3bcdefg

$1081.7 \mathrm{bcdefg}$

1038.3bcdefg

$1008.5 \mathrm{bcdefg}$

1005.6bcdefg

990.3 bcdefg

942.0bcdefg

922.5bcdefg

820.4cdefg

788.6cdefg

745.0defg

742.8defg

694.1defg

644.3defg

642.8defg

$564.3 \mathrm{efg}$

543.8efg

$510.7 \mathrm{fg}$

467.6fg

$421.3 \mathrm{fg}$

$376.2 \mathrm{fg}$

$339.5 \mathrm{fg}$

297.3fg

289.0fg

$256.8 \mathrm{fg}$

$208.5 \mathrm{fg}$

204.8fg

$190.3 \mathrm{fg}$

$126.3 \mathrm{~g}$

$109.6 \mathrm{~g}$

**

S. E. \pm

753.56

Means followed by the same letters are not significantly $(\mathrm{P} \leq 0.001)$ different according to Duncan's Multiple Range Test (DMRT). Means in parentheses are transformed values 